\title{
AWARENESS AND SEXUAL BELIEFS OF YOUNG POLISH ADULTS IN TERMS OF THEIR QUALITY OF LIFE
}

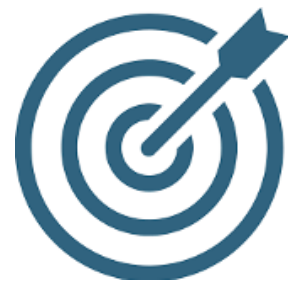

THE ASSESSMENT OF SEXUAL AWARENESS AND SEXUAL BELIEFS IN THE CONTEXT OF QUALITY OF LIFE

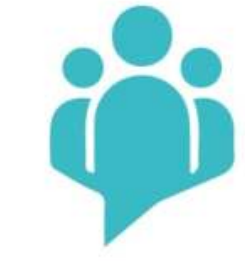

38

$100 \%$ female age: $21,4 \pm 1,3$

Sexual Awareness Questionnaire (SAQ)

SeXUal Beliefs Questionnaire (SBQ) - Female Version

Sexual Quality of LifE QueStionNaIRE - Female (SQOL-F)

Sexual Life Satisfaction Questionnaire (SLSQ)

\section{RESULTS}

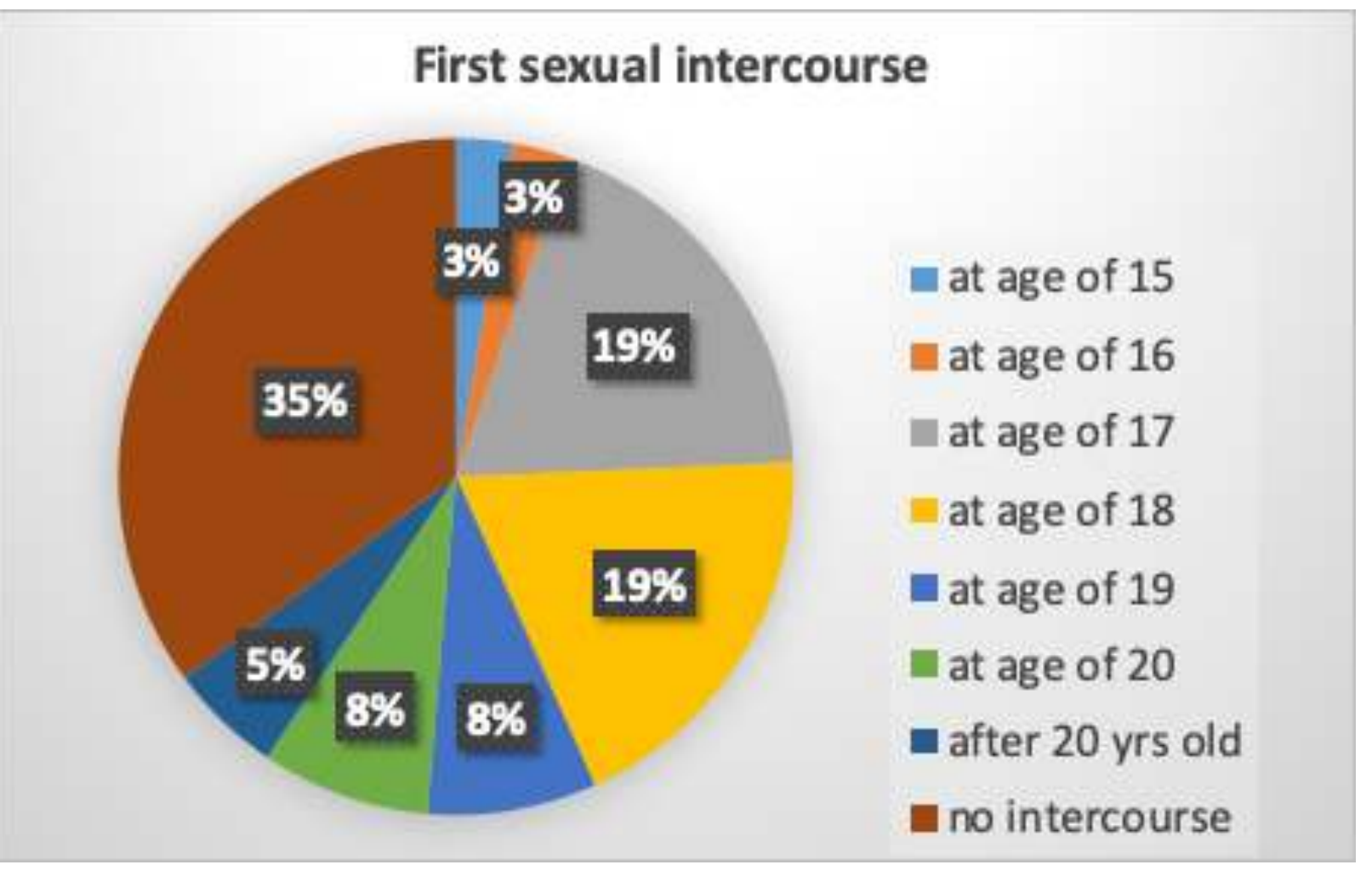

Table: Correlations between SQoL-F and SAQ, SLSQ, and SBQ

\begin{tabular}{|c|c|c|c|}
\hline & \multicolumn{2}{|c|}{ SQoL-F } \\
\hline & & $r_{s}$ & p-value \\
\hline \multirow{5}{*}{ SAQ } & $\begin{array}{l}\text { D1-sexual- } \\
\text { consciousness }\end{array}$ & $-0,46$ & 0,003 \\
\hline & $\begin{array}{l}\text { D2-sexual- } \\
\text { monitoring }\end{array}$ & 0,32 & 0,054 \\
\hline & $\begin{array}{l}\text { D3-sexual- } \\
\text { assertiveness }\end{array}$ & $-0,48$ & 0,002 \\
\hline & $\begin{array}{l}\text { D4 sex-appeal } \\
\text { consciousness }\end{array}$ & $-0,23$ & 0,170 \\
\hline & TOTAL_SAQ & $-0,25$ & 0,130 \\
\hline \multicolumn{2}{|c|}{ TOTAL_SLSQ } & 0,73 & $<0,001$ \\
\hline \multirow{7}{*}{ SBQ } & $\begin{array}{l}\text { F1 sexual } \\
\text { conservatism }\end{array}$ & $-0,07$ & 0,672 \\
\hline & $\begin{array}{l}\text { F2 sexual desire } \\
\text { and pleasure }\end{array}$ & $-0,50$ & 0,002 \\
\hline & $\begin{array}{l}\text { F3 age related } \\
\text { beliefs }\end{array}$ & 0,12 & 0,473 \\
\hline & $\begin{array}{l}\text { F4 body-image } \\
\text { beliefs }\end{array}$ & $-0,05$ & 0,767 \\
\hline & $\begin{array}{l}\text { F5 denying } \\
\text { affection primacy }\end{array}$ & $-0,41$ & 0,011 \\
\hline & $\begin{array}{l}\text { F6 motherhood } \\
\text { primacy }\end{array}$ & $-0,07$ & 0,695 \\
\hline & Total_SBQ & $-0,25$ & 0,131 \\
\hline
\end{tabular}

\section{CONCLUSIONS}

- The lower tendency to think and reflect about the nature of one's sexuality is correlated with higher Sexual Quality of Life

- The lower tendency to be assertive about the sexual aspects of one's life is correlated with higher Sexual Quality of Life

- The affection, love and agreement between partners are correlated with Sexual Quality of Life

- The idea that sex is a male activity, where women must control their sexual urges and pleasure since these are sinful experiences is negatively correlated with Sexual Quality of Life

- This preliminary report needs further studies

Acknowledgements: The study „Awareness and sexual beliefs of young adults in terms of their quality of life” was funded by the Ministry of Science and Higher Education: registration number STM.E020.18.035 